\title{
Assessing the impact of spear fishing by using competitions records and underwater visual censuses
}

\author{
Pablo Pita ${ }^{1}$, Juan Freire ${ }^{2}$ \\ ${ }^{1}$ Department of Applied Economics, Faculty of Economics and Business Administration, University of Santiago de \\ Compostela, Av. Burgo das Nacións s/n, 15782, Santiago de Compostela, Spain. E-mail: pablo.pita@usc.es \\ ${ }^{2}$ Teamlabs, Duque de Alba 15, 28012, Madrid, Spain.
}

\begin{abstract}
Summary: Recreational fishers are increasingly competing for space and resources with commercial fishers worldwide, but have been poorly studied. In particular, the impacts of spearfishing competitions on the temperate fish assemblages have seldom been analysed. In Galicia (NW Spain), there are currently 5000 spear fishers, and 500 of them participate in spearfishing competitions. An historic archive of spearfishing competitions was used to assess their influence on the subsequent competitions in the area and to analyse their effect on the fish abundances estimated by underwater visual censuses. The annual recreational catch of the spear fishers was also estimated and comparisons with the commercial landings were performed. The spear fishers targeted 29 species, although six accounted for $95 \%$ of the catch. Most of the species show low vulnerabilities to fishing pressure and only Dicentrarchus labrax, among frequently caught species, can be considered as moderately vulnerable. The overall impact of spearfishing competitions on fish populations was limited, although some competitions temporarily reduced the abundances of Labrus bergylta, the main target species, by up to $83 \%$. Spear fishers caught a large proportion of the total catch of common species, with recreational catches of some species (e.g. L. bergylta) matching or exceeding the commercial catch. The inclusion of this fishery in the management models of the coastal ecosystems is strongly recommended.
\end{abstract}

Keywords: underwater visual censuses; fish assemblages; recreational fisheries; spear fishing; fishing impacts; coastal ecosystems.

Evaluación del impacto de la pesca submarina mediante el uso de registros de concursos y censos visuales subacuáticos

Resumen: Los pescadores recreativos compiten cada vez más intensamente por el espacio y los recursos con los pescadores comerciales en todo el mundo, pero han sido poco estudiados. En particular, rara vez se han analizado los impactos de los concursos de pesca submarina sobre las comunidades de peces propias de las regiones templadas. En Galicia (noroeste de España), en la actualidad hay 5000 pescadores submarinos, y 500 de ellos participan en concursos. Se utilizó un archivo histórico de competiciones de pesca submarina para evaluar su influencia sobre los concursos celebrados posteriormente en la zona y para analizar su efecto sobre las abundancias de peces, estimadas mediante censos visuales subacuáticos (UVC). Además, se estimaron las capturas recreativas anuales de los pescadores submarinos y se realizaron comparaciones con los desembarques comerciales. Los pescadores submarinos capturaron 29 especies, aunque seis representaron el 95\% de sus capturas. La mayor parte de las especies muestran bajas vulnerabilidades a la presión pesquera y sólo Dicentrarchus labrax, de entre las especies capturadas con frecuencia, puede ser considerada como moderadamente vulnerable. El impacto global de los concursos de pesca submarina sobre las poblaciones de peces fue limitado, aunque algunos concursos redujeron temporalmente las abundancias de Labrus bergylta, la principal especie objetivo, hasta en un 83\%. Los pescadores submarinos obtuvieron una relevante proporción de las capturas totales sobre las especies comunes, con las capturas recreativas sobre algunas de ellas (e.g. L. bergylta) siendo equivalentes o superiores a las comerciales. Se recomienda encarecidamente la inclusión de esta pesquería en los modelos de gestión de los ecosistemas costeros.

Palabras clave: censos visuales subacuáticos; comunidades de peces; pesquerías recreativas; pesca submarina; impactos pesqueros; ecosistemas costeros.

Citation/Como citar este artículo: Pita P., Freire J. 2016. Assessing the impact of spear fishing by using competitions records and underwater visual censuses. Sci. Mar. 80(1): 27-38. doi: http://dx.doi.org/10.3989/scimar.04352.15A

Editor: J. Lloret.

Received: September 29, 2015. Accepted: November 25, 2015. Published: January 20, 2016.

Copyright: () 2016 CSIC. This is an open-access article distributed under the Creative Commons Attribution-Non Commercial Lisence (by-nc) Spain 3.0. 


\section{INTRODUCTION}

There is growing concern about the effects of recreational fisheries on world ecosystems (Schroeder and Love 2002, Cooke and Cowx 2006, Lewin et al. 2006). This sector obtains approximately $12 \%$ of the global fish harvest (Cooke and Cowx 2004), rivalling with commercial fisheries in some regions (Coleman et al. 2004). It is difficult to understand how, despite the growing social and economic interest of the sector and the increasing conflicts with the commercial fisheries, there are few studies on the fish communities targeted by recreational fisheries (Kearney 2001, Arlinghaus 2006, Pawson et al. 2008). Moreover, the use of inappropriate management models based on short-term policy decisions is seriously threatening the long-term sustainability of many recreational fisheries (Kirkegaard and Gartside 1998, Arlinghaus 2006).

Spear fishing is an ancient fishing technique (Yellen et al. 1995), but it is particularly controversial and generates intense debate (Lincoln Smith et al. 1989, Smith and Nakaya 2002). There are few studies on its consequences (Jouvenel and Pollard 2001, Morales-Nin et al. 2005), and these are contradictory. While (Smith and Nakaya 2002) consider the spear fishery ecologically sustainable, other authors have found large negative effects on ecosystems (Rusell 1977, Harmelin et al. 1995, Coll et al. 2004, Lloret et al. 2008, Frisch et al. 2012). This fishery has been regulated in a precautionary way (Morales-Nin et al. 2005) and has even been subjected to several restrictions (Smith and Nakaya 2002) because of this lack of information for decisionmaking and management (Pawson et al. 2008, Godoy et al. 2010). Moreover, many spear fishers participate in competitions, mostly in the countries of southern Europe (Pawson et al. 2008), to the point that some of the competition records have already been used to assess changes in marine ecosystems (Coll et al. 2004, Steffe et al. 2007, Pita and Freire 2014). Surprisingly, the impact of these competitions on the local fish populations has not yet been studied, although they may result in very abundant catches in a short period.

A spear fishery has been operating since the midtwentieth century in Galicia (NW Spain) and is increasingly popular (Rodríguez and León 1997, Pita and Freire 2014). There were 2916 spearfishing licences granted in the year 2000 and in recent years the figure has reached more than 5000 (Xunta de Galicia, pers. comm). Furthermore, approximately 500 spear fishers participate each year in spearfishing competitions, but to date there is no information on their impact on the coastal ecosystems. Moreover, the coastal fish communities of Galicia have also been traditionally exploited by a very heterogeneous multi-gear commercial fleet using mainly trawls, longlines, gillnets and purse seines (Freire and García-Allut 2000). Many of these coastal fisheries are currently mismanaged and overexploited (Freire and García-Allut 2000, Freire et al. 2002, Pita and Freire 2014). Therefore, it is important to obtain information on the effects of the spear fishery in order to manage the ecosystems comprehensively by developing integrated coastal management plans (Lloret and Font 2013).
The historical archive of the Federación Galega de Actividades Subacuáticas (Galician Federation of Underwater Activities, FEGAS) has contained comprehensive information on the spearfishing competitions held in Galicia since they started in 1953 (Pita and Freire 2014). In this paper, this archive was used to analyse the impact of spearfishing competitions for the first time. It was expected that the competitions cause temporary declines in the fish abundances of the assemblages of the area. The initial assumptions were that these reductions are dependent on the time since the completion of the competition, and on the size of catches. To test these hypotheses, the FEGAS archive was used to analyse (1) the changes in the catches obtained in consecutive competitions held in the same area, in relation to the time elapsed between the competitions; and (2) the effect of the competitions on the abundances of the coastal fish assemblages, estimated alongside a monitoring programme performed by underwater visual censuses (UVCs).

In addition, a survey with Galician spear fishers was conducted to ask about their seasonal fishing effort. This information was used, along with catch per unit effort (CPUE) data and information on the catch frequency by species derived from the FEGAS archive, to estimate their annual recreational catch and to make comparisons with the commercial catches of the same species. Finally, the index of vulnerability to fishing (Cheung et al. 2005) of each species was used to provide information that could help in the decisionmaking processes of the management of the coastal ecosystems.

\section{MATERIALS AND METHODS}

\section{Spear fishing in Galicia}

Spear fishing in Galicia is exclusively a breathhold activity in which the spear fishers catch coastal fish (and some cephalopods) using spear guns. It is a recreational activity and spear fisher catches cannot be legally sold. Furthermore, the spear fishers must pay a fishing licence and their effort is controlled by limiting the number of fishing days and by imposing a bag limit that is currently $5.0 \mathrm{~kg}$ spear-fisher ${ }^{-1}$ day $^{-1}$ (Xunta de Galicia 2009). By way of illustration, in 2007 the number of fishing days was 220 , so the annual total allowable catch was 5819 t (5290 licences were granted in 2007).

Spearfishing competitions take place in coastal areas that vary between a few tens of metres and several kilometres long, mainly in the rocky reefs outside the bays and in areas exposed to waves (Pita and Freire 2014). The spear fishers have a limited time to obtain the heaviest catch without complying with the daily quota limit, but some of the rules are more restrictive than those that regulate recreational spear fishing. There are limitations regarding the minimum weight of the fish $(1 \mathrm{~kg})$ and species: only one Conger conger (L.), three Balistes capriscus (Gmelin) and five Mugilidae spp. are allowed per spear fisher. Moreover, cephalopods and fish of the superclass Agnatha, the class Chon- 
drichthyes and the orders Pleuronectiformes and Lophiiformes of the class Actinopterygii are not permitted. However, in some of the first competitions, these rules were not strictly followed and some spear fishers made a few anecdotal bycatches of some of these fish species (Pita and Freire 2014).

The FEGAS archive (see Pita and Freire 2014 for a detailed description) contains comprehensive information on the length in hours, the number of spear fishers, the location and the date of each competition. It also contains the number of fish and the weight of the catch per spear fisher (the weight of $C$. conger was recorded separately) and the weight of the largest fish caught by spear fishers in each competition (trophy fish). In general, most of the trophy fish were identified correctly to species level but some species were occasionally grouped together under the same morphotype, or different morphotypes were used for forms of the same species. Thus, spear fishers differentiated between "pintos" and "maragotas" (see VillegasRíos et al. 2013a), which are in fact different forms of Labrus bergylta (Ascanius). The white seabream morphotype grouped together the species Diplodus annularis (L.), D. sargus (L.) and $D$. vulgaris (Geoffroy SaintHilaire) and the mullet morphotype included Chelon labrosus (Risso), Liza aurata (Risso) and L. ramada (Risso). The term species was used generically to refer to morphotype (Table 1).

\section{Changes in competition catch rates}

It was hypothesized that the catches in a competition would be smaller when another competition had been held previously in the same area. In addition, the shorter the time between the competitions, the greater the decrease in the catch. To test this hypothesis, the information in the FEGAS archive was used to identify and group the compe-

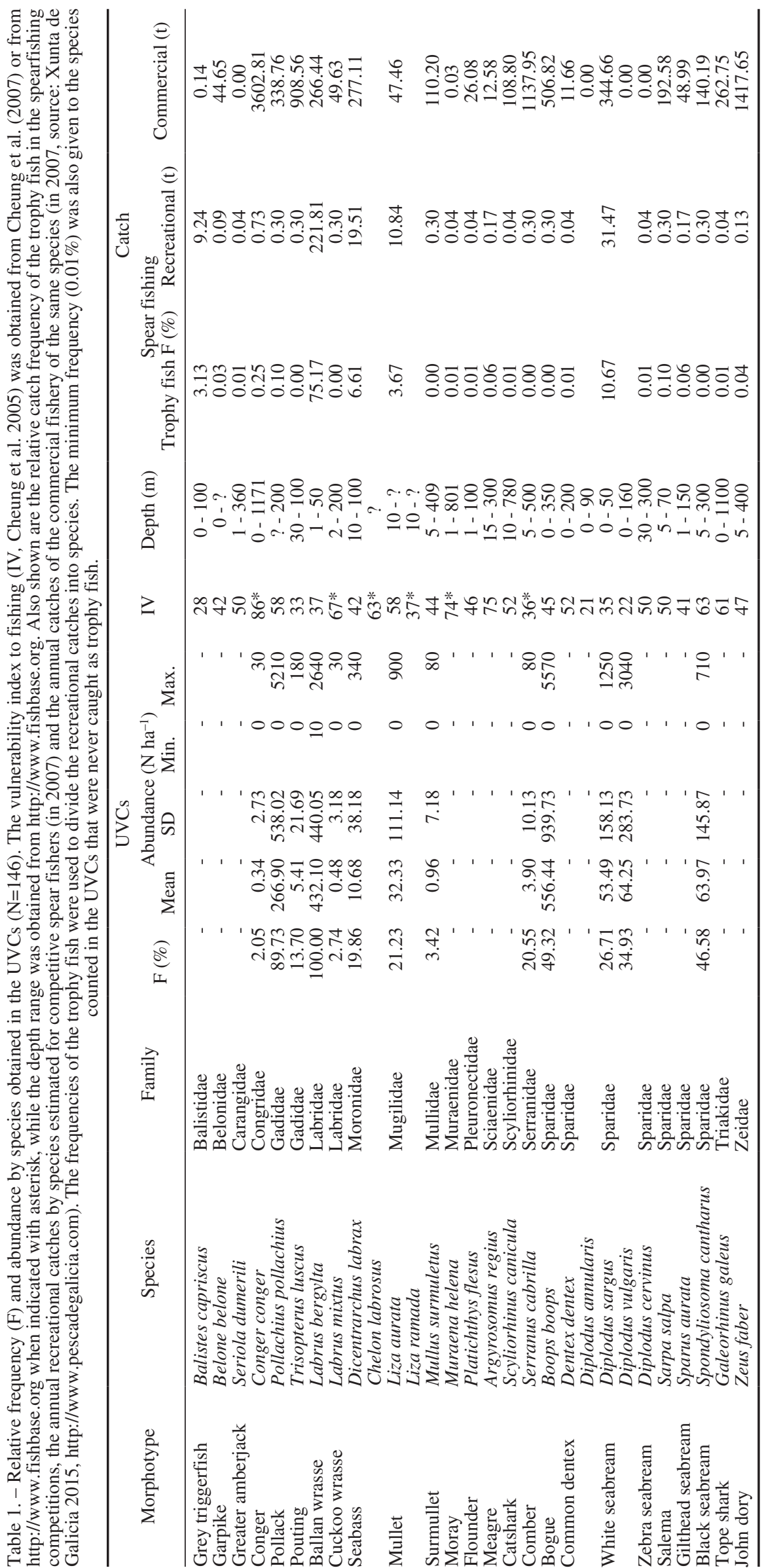




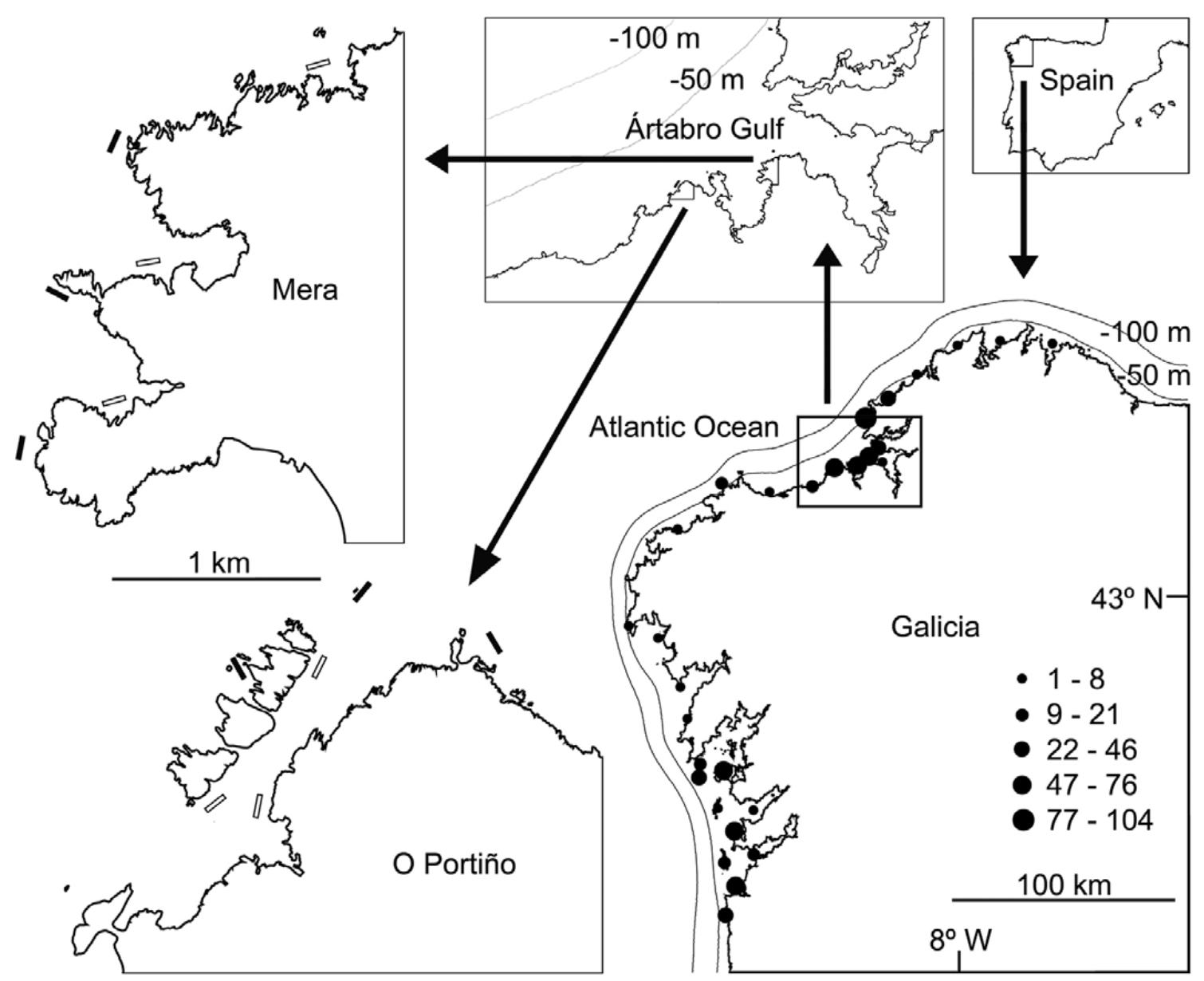

Fig. 1. - Map of the study area indicating the number of spear fishing competitions held in each area (the size of the point indicates the number of competitions). The locations of the rocky reefs in the Artabro Gulf (O Portiño and Mera) in which the UVCs were carried out are shown. The lines indicate the locations of the transects $(100 \mathrm{~m})$. The transects in areas exposed to waves are drawn in black and the transects in protected areas are drawn in white.

titions held in nearby areas. Thereby, 29 zones were obtained, with an average length of 15.8 \pm 7.4 (SD) km (Fig. 1).

In each of these zones, the rate of change in the CPUE between pairs of consecutive competitions $\left(\mathrm{T}_{\mathrm{C} 1 \rightarrow \mathrm{C} 2}\right)$ was calculated as the ratio between the catches per spear fisher and hour of each pair of competitions:

$$
\left(\mathrm{T}_{\mathrm{C} 1 \rightarrow \mathrm{C} 2}\right)=\mathrm{CPUE}_{\mathrm{C} 2} \div \mathrm{CPUE}_{\mathrm{C} 1}
$$

where $\mathrm{CPUE}_{\mathrm{C} 1}$ and $\mathrm{CPUE}_{\mathrm{C} 2}$ are the catches $(\mathrm{kg})$ per spear fisher and hour in the first and second competition, respectively.

\section{Changes in fish abundances}

It was hypothesized that the catches made in a competition would lead to decreases in the fish densities in the area. It would be expected that the shorter the time elapsed since the competition and the larger the catches obtained, the greater the impact on the fish assemblages.

To test these hypotheses, a rocky reef area around the Ría de A Coruña $\left(43^{\circ} 22^{\prime} \mathrm{N} ; 8^{\circ} 22^{\prime} \mathrm{W}\right)$ was selected and the densities of the fish assemblages were moni- tored by UVCs for four years (2003 to 2006). UVCs were used due to their low impact on the populations studied (Schmitt 2002), their great flexibility for all types of environments and species (De Girolamo and Mazzoldi 2001), and the fact that was proven to be the most suitable method in a study performed in the area (Pita et al. 2014). Monitoring was conducted in two coastal zones with similar orientations to waves and on both sides of the Ría: Mera, to the northeast, and $\mathrm{O}$ Portiño, to the west (Fig. 1). The UVCs were performed every three months, preferably in February, May, August and November.

Wave exposure is one of the physical factors that most determines the ecology of fish communities in shallow waters (Gust et al. 2001, Micheli et al. 2005, Pais et al. 2007). Therefore, in each zone one sector exposed to waves and one unexposed sector were selected and three fixed transects were positioned in each of the sectors. The UVCs were performed in the locations most frequented by spear fishers (an expert spear fisher with extensive knowledge of the area previously identified the locations). Although the UVCs were carried out in pairs for security reasons, the same diver, who had previous experience in carrying out UVCs, made all the observations (see Pita et al. 2014 for a 
Table 2. - Significant variables, error distribution and link, explained deviance and degrees of freedom (df) of the GAM fitted to the rate of change of the CPUE between pairs of consecutive competitions and to the abundance of Labrus bergylta obtained by UVCs. The models fitted to the abundance of fish species with non-significant variables are not shown.

\begin{tabular}{llccc}
\hline \multicolumn{1}{c}{ Response } & Explanatory & Error & Link & Deviance \\
\hline Log $\left[\left(\mathrm{CPUE}_{\mathrm{n}} / \mathrm{CPUE}_{\mathrm{n}-1}\right)+1\right]$ & Time (days) & Gaussian & Log & 0.00 \\
Abundance of Labrus bergylta & Weight $(\mathrm{g})$ & Gamma & Log & 1.00 \\
\hline
\end{tabular}

detailed description of the UVC methods used here). Therefore, the intra-observer variability was kept under control. The transect width varied depending on the visibility, which was estimated according to a 1-mmarked guide rope. The depth and temperature were obtained with a dive computer (recorded every $4.0 \mathrm{~s}$ ). Over the year, the water temperature varied between $9.0^{\circ} \mathrm{C}$ and $18.4^{\circ} \mathrm{C}$ and the maximum depth was $19.9 \mathrm{~m}$.

The fish assemblages were censused along the $100-\mathrm{m}$-long transects. The divers swam slowly $(5.0 \mathrm{~m}$ $\mathrm{min}^{-1}$ ) along the transect, noting down the abundances of the species generally caught by spear fishers (cryptic species and smaller species of the families Bleniidae, Gobiidae, Labridae and Sparidae were not included). Fish were identified to species level, except for the family Mugilidae, which are difficult to identify in low-visibility waters.

\section{Recreational catch of the spear fishery}

In 2003, FEGAS spear fishers were requested to provide information on their fishing effort. A questionnaire was published on the FEGAS webpage (http:// www.fegas.net) and in the magazine Espacio Submarino (which was received by all FEGAS members). The questionnaire asked spear fishers whether they participated in spearfishing competitions. It also asked spear fishers to quantify their fishing effort: number of fishing hours per day and number of fishing days per month, for each season of the year.

\section{Vulnerability of fish species}

The index of vulnerability to fishing of each species was obtained from the list provided by Cheung et al. (2007) and from http://www.fishbase.org for those species absent from the Cheung et al. (2007) list. This index is based on ecological characteristics and life history of marine fish (Cheung et al. 2005) and has four levels of vulnerability: low (1-40), moderate (40-60), high (60-80) and very high (80-100). The vulnerability index of the catches of the recreational and the commercial fisheries was also estimated by the arithmetic mean of the vulnerability of the fish species, weighted by their respective catches (see Lloret et al. 2008).

\section{Data analysis}

Additive multiple regression models (GAM, Hastie and Tibshirani 1990, Wood 2006) were used to analyse (1) the relationship between the rates of change in the CPUE between pairs of consecutive competitions held in the same area and the time elapsed between them; and (2) the relationship between the densities of the species targeted by spear fishers, determined by UVCs, and the time elapsed since the completion of the last competition in the area. In addition, the influence of the total weight of the catch $(\mathrm{kg})$ obtained in the competition was evaluated (Table 2).

To minimize undesired influences in the models used to analyse the changes in the competition catch rates (1), the maximum period considered between two competitions was one month. For the same reason, a one-month period was also the maximum time considered between UVCs and competitions in the models to analyse the changes in the fish abundances (2). In addition, competitions held close together (less than 30 days) were considered as a single event, the catch was added and the time was considered up to the end of the second competition.

Boops boops (L.) is a very frequent species that lives in highly mobile large schools and does not normally exceed $20.0 \mathrm{~cm}$ (Bauchot 1987). For this reason, it is not a target species for the spear fishers (it is absent from the FEGAS archive). Consequently, this species was excluded from the analysis (2) to prevent its natural dynamics from hiding the cause-effect relationships between competitions and the abundances of target species.

The models were fitted, selected and validated with the $m g c v$ package (Wood 2000) of the statistical package R, version 3.2.2 (R Core Team 2008). Different models were assessed with the response variable transformed, with different error structures and link functions and using smoothed functions for the response variables, with penalized thin-plate regression splines (Wood 2003) and the flexibility by default of the $\mathrm{mgcv}$ package (Wood 2000). The most appropriate models were selected based on the Akaike criterion (Akaike 1973) whenever possible, and secondarily on the percentage of explained variance.

The gam.check tool of the mgcv package, which plots the deviance residuals against approximate theoretical quantiles of the deviance residual distribution, according to the fitted model, was used to check the residuals (Wood 2006). Models with over-dispersed and/ or anomaly-distributed residuals were discarded. The predict tool of the $m g c v$ package was used to obtain inferences from the definitive model.

The annual recreational catches of the spear fishers (i.e. recreational catches obtained out of competitions in 2007) were estimated by combining their seasonal effort, obtained from the questionnaire, with the seasonal average CPUE (kg spear-fisher $\left.{ }^{-1} \mathrm{~h}^{-1}\right)$ obtained from the FEGAS archive $(\mathrm{N}=13427)$. Thereafter, the estimated annual catch was distributed among the species by using the catch frequency of each species in the trophy fish record of the FEGAS archive, assigning the minimum frequency $(0.01 \%)$ to the species censed in the UVCs that were not present in the trophy 


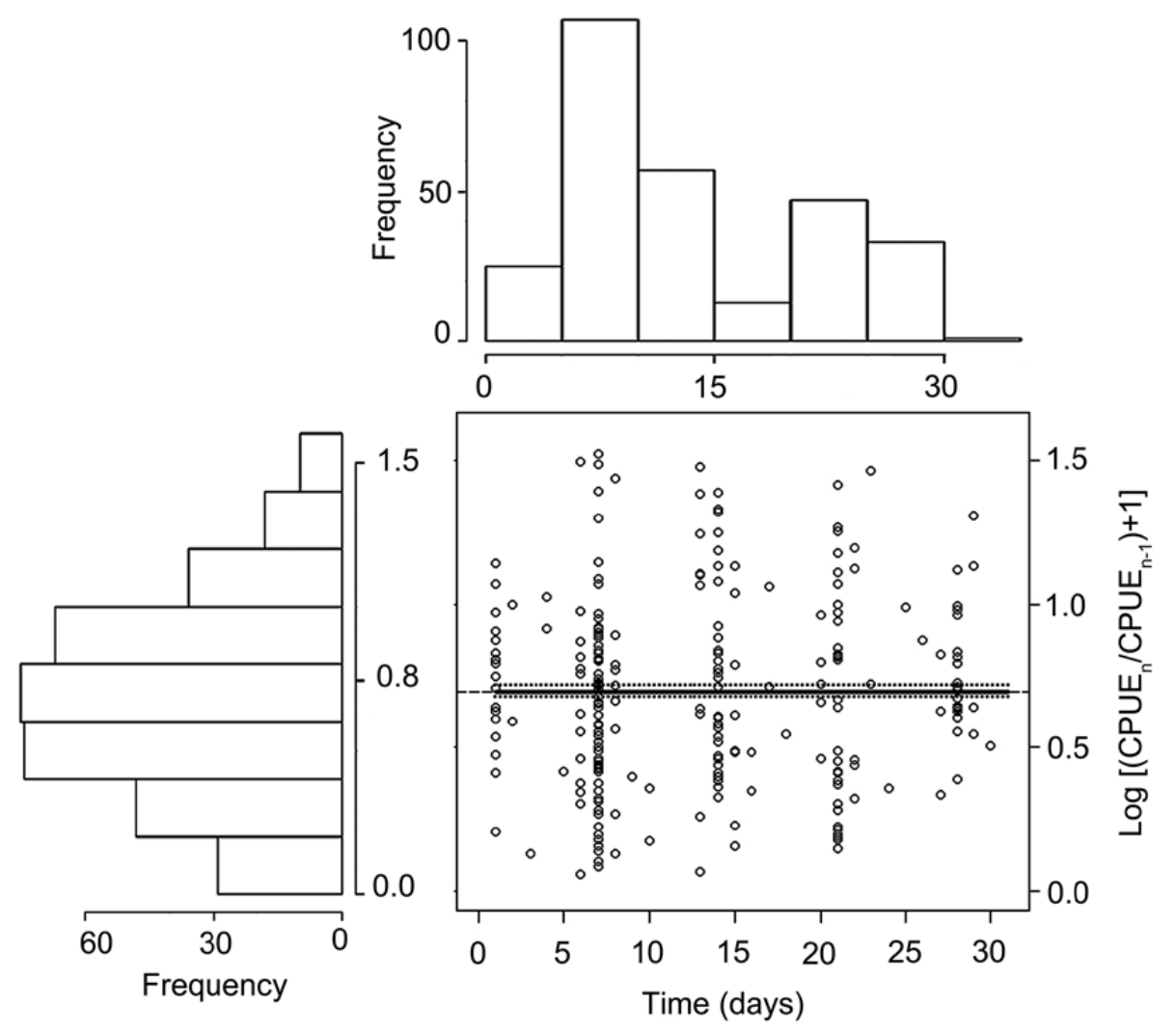

Fig. 2. - Partial effect of the time between pairs of competitions held in the same area (one month maximum) on the rate of change of the CPUE (logarithmic scale) between 1964 and 2007. The observations (points), the prediction (continuous lines) and their standard deviation (dashed lines) estimated by GAM are shown. Histograms of the frequencies of the two variables are also shown.

fish record. The catches assigned to morphotypes that grouped different species were distributed equally between the species under the common name (Table 1).

\section{RESULTS}

\section{Changes in competition catch rates}

Based on the information contained in the FEGAS archive, 864 spearfishing competitions were held in Galicia between 1953 and 2007, in which $101 \mathrm{t}$ of fish of 23 species ( 15 families) were caught (Table 1). Competitions lasted $4.7 \pm 1.3 \mathrm{~h}$ on average and in each of them an average of $22.1 \pm 12.9$ spear fishers participated. Their mean CPUE was $1.6 \pm 1.9 \mathrm{~kg}$ spear-fisher ${ }^{-1} \mathrm{~h}^{-1}$.

A total of 244 pairs of competitions were analysed in 24 of the 29 studied areas (the maximum period considered between competitions was one month). The number of competitions has increased steadily over time, so most of the pairs of competitions analysed were completed after 2000 (57.4\% of total), 38.1\% were completed between 1990 and 2000, and only $4.5 \%$ before 1990 .

The average time elapsed between pairs of competitions was $13.4 \pm 8.2$ days. The average catch was $87.5 \pm 105.6 \mathrm{~kg}$ of fish per competition and overall, $21.1 \mathrm{t}$ were extracted. The average rate of change in the CPUE between the pairs of competitions was $1.1 \pm 0.8$. The model fitted to this rate of change (Table 2) did not show a time effect $(p=0.342)$. Therefore, the catch obtained in one competition did not influence the catch obtained in the following competition in the area, independently of the time that elapsed between them (Fig. 2).

\section{Changes in fish abundances}

Bad weather and rough sea conditions prevented the completion of $24.0 \%$ of the scheduled UVCs. Therefore, the divers carried out 146 UVCs $(48.7 \mathrm{~h}$ of observation) in the study area and 18757 fish belonging to 13 species ( 8 families) were counted. The average per UVC was $128.5 \pm 132.3$ fish and the average density was $1491.2 \pm 1271.4 \mathrm{~N} \mathrm{ha}^{-1}$. The most frequent species were L. bergylta (present in $100.0 \%$ of the UVC) and Pollachius pollachius (L.) (89.7\%), eight species showed medium frequencies (from $13.7 \%$ to $49.3 \%$ ), and Mullus surmuletus (L.), Labrus mixtus (L.) and C. conger were counted only occasionally (from $2.1 \%$ to $3.4 \%$ ). The most abundant species were $B$. boops $\left(556.4 \pm 939.7 \mathrm{~N} \mathrm{ha}^{-1}\right)$, L. bergylta $\left(432.1 \pm 440.1 \mathrm{~N} \mathrm{ha}^{-1}\right)$ and P. pollachius $\left(266.9 \pm 538.0 \mathrm{~N} \mathrm{ha}^{-1}\right)$. M. surmuletus, $L$. mixtus and $C$. conger were the least abundant species (from $0.3 \pm 2.7 \mathrm{~N} \mathrm{ha}^{-1}$ to $1.0 \pm 7.2 \mathrm{~N} \mathrm{ha}^{-1}$, Table 1).

In the same time and area, 27 spearfishing competitions were held, including a Spanish competition with many experienced spear fishers (Fig. 3). In these competitions, the spear fishers caught $2.39 \mathrm{t}$ of fish (on average $88.4 \pm 120.1 \mathrm{~kg}$ per competition). On average, 17.2 \pm 10.7 spear fishers participated in each competition and obtained $1.0 \pm 0.7 \mathrm{~kg} \mathrm{~h}^{-1}$ of fish per spear fisher. 


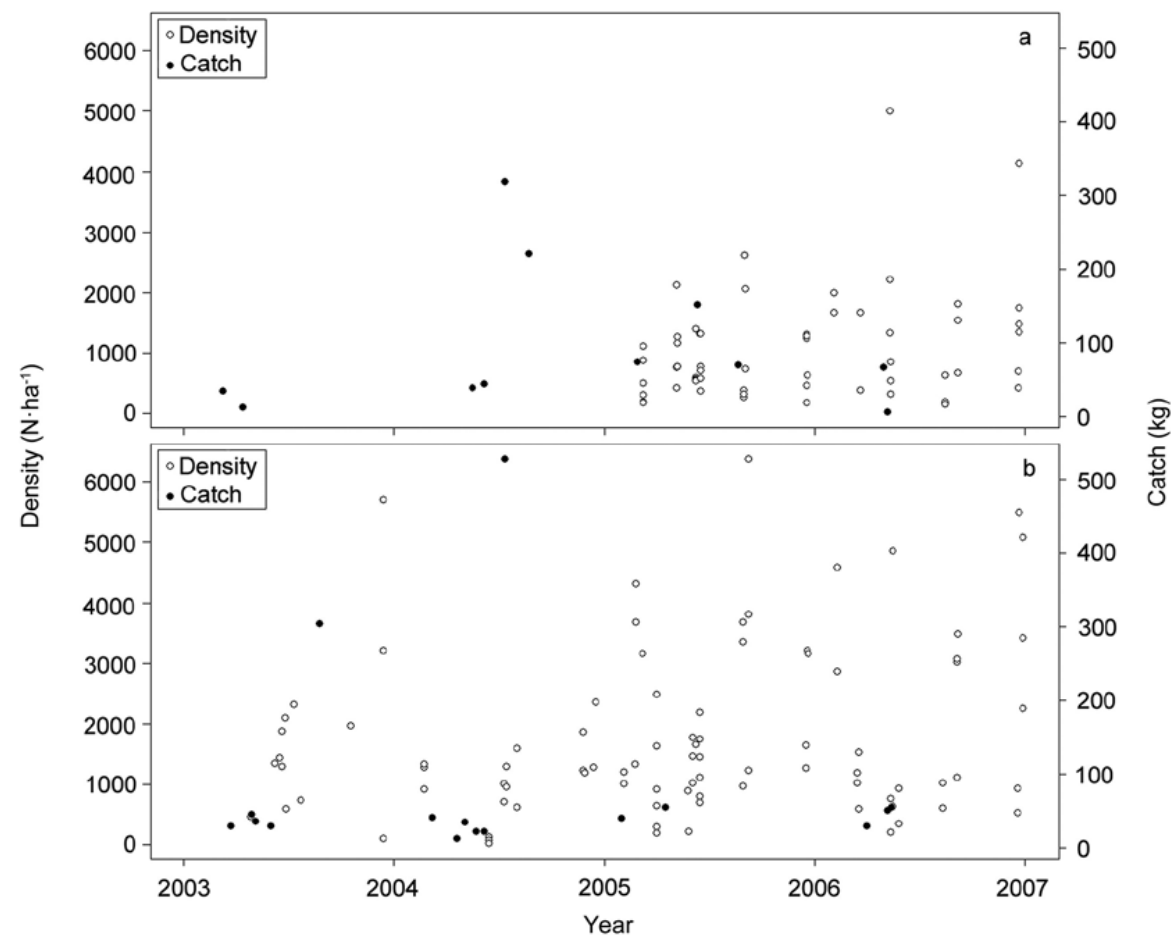

Fig. 3. - Catches obtained in the spearfishing competitions (black points) and abundances of the fish assemblages targeted by the spear fishery obtained by UVCs (white points) in Mera (a) and O Portiño (b) between 2003 and 2007.

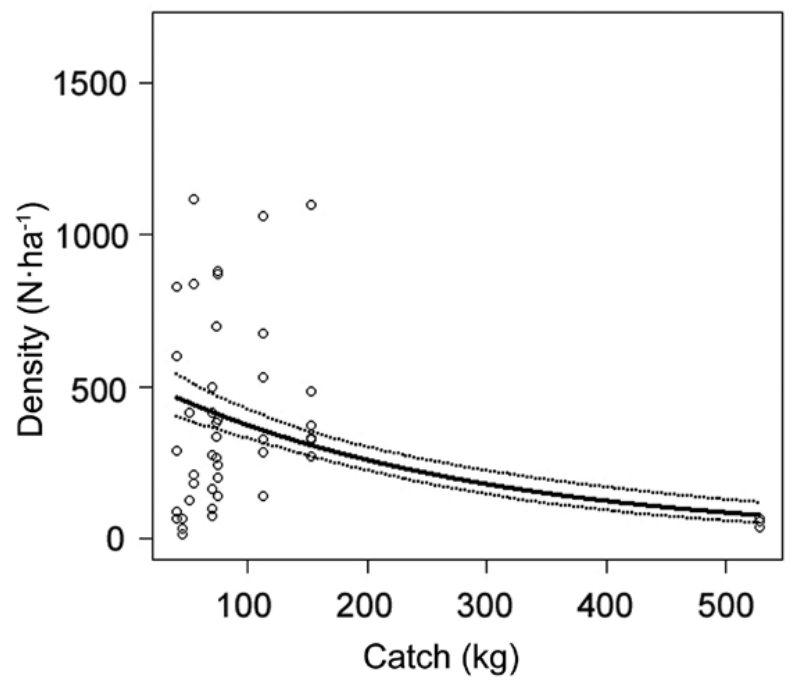

Fig. 4. - Partial effect of the catches in the spearfishing competitions on the abundance of Labrus bergylta obtained by UVCs. The observations (points), the prediction (continuous lines) and their standard deviation (dashed lines) estimated by GAM are shown.

Table 3. - Results of the GAM fitted to the rate of change of the CPUE between pairs of consecutive competitions and to the abundance of Labrus bergylta obtained by UVCs. The estimated parametric coefficients, the standard deviation (sd) and associated $\mathrm{p}$ value are shown. The degrees of freedom (df) of the smoothed terms was also shown.

\begin{tabular}{|c|c|c|c|}
\hline \multirow{2}{*}{ Model } & \multicolumn{2}{|c|}{ Parametric coefficients } & \multirow{2}{*}{$\begin{array}{l}\text { Smooth terms } \\
\text { df }\end{array}$} \\
\hline & Estimate & $\mathrm{sd} \quad \mathrm{p}$ & \\
\hline \multicolumn{4}{|c|}{$\log \left[\left(\mathrm{CPUE}_{\mathrm{n}} / \mathrm{CPUE}_{\mathrm{n}-1}\right)+1\right]$} \\
\hline Intercept & -0.3620 & $0.0303<0.0001$ & \\
\hline Time & - & -0.3420 & 0.0003 \\
\hline \multicolumn{4}{|c|}{ Density of Labrus bergylta } \\
\hline Intercept & 6.2910 & $0.1586<0.0001$ & 1 \\
\hline Weight & 0.0000 & $0.0000 \quad 0.0002$ & - \\
\hline
\end{tabular}

Neither the overall density nor the density of each target species, analysed separately, varied significantly with the time that had elapsed since the last competition held in the zone. However, the densities of L. bergylta were negatively influenced by the weight of the catches taken in the competitions (Table 3), decreasing significantly after the competitions $(\mathrm{p}<0.001)$. Furthermore, the highest decreases $(83.0 \%)$ took place after the competitions with larger catches (Fig. 4).

\section{Recreational catch of the spear fishery}

Based on the information obtained in the questionnaires answered by spear fishers $(\mathrm{N}=54)$, the annual fishing effort was on average $307.6 \pm 134.6 \mathrm{~h}$ spearfisher $^{-1}$. This fishery showed large seasonal variations: the highest effort was exerted during the summer $\left(149.7 \pm 81.1 \mathrm{~h}\right.$ spear-fisher $\left.{ }^{-1}\right)$, matching the highest CPUE in the competitions (1.8 kg spear-fisher $\left.{ }^{-1} \mathrm{~h}^{-1}\right)$. In winter, the spear fishers did not fish for many hours $\left(39.8 \pm 30.1 \mathrm{~h}\right.$ spear-fisher $\left.{ }^{-1}\right)$ and they were less effective $\left(0.98 \mathrm{~kg}\right.$ spear-fisher-1 $\mathrm{h}^{-1}$, Fig. 5).

Most of the spear fishers participated in competitions (57\% of total). They showed a higher annual fishing effort $\left(365.7 \pm 135.7 \mathrm{~h}_{\text {spear-fisher }}{ }^{-1}\right)$ than the spear fishers that did not participate in competitions $(229.2 \pm 85.5 \mathrm{~h}$ spear-fisher $\left.{ }^{-1}\right)$. They also distributed their effort more uniformly throughout the year (Fig. 5).

The questionnaire was answered by $6.2 \%$ of the spear fishers that participate in competitions in Galicia (approximately 500), but spear fishers who did not participate accounted for only $0.5 \%$ of the sampling universe. Thus, the annual recreational catch (during 2007) was exclusively estimated for competition 


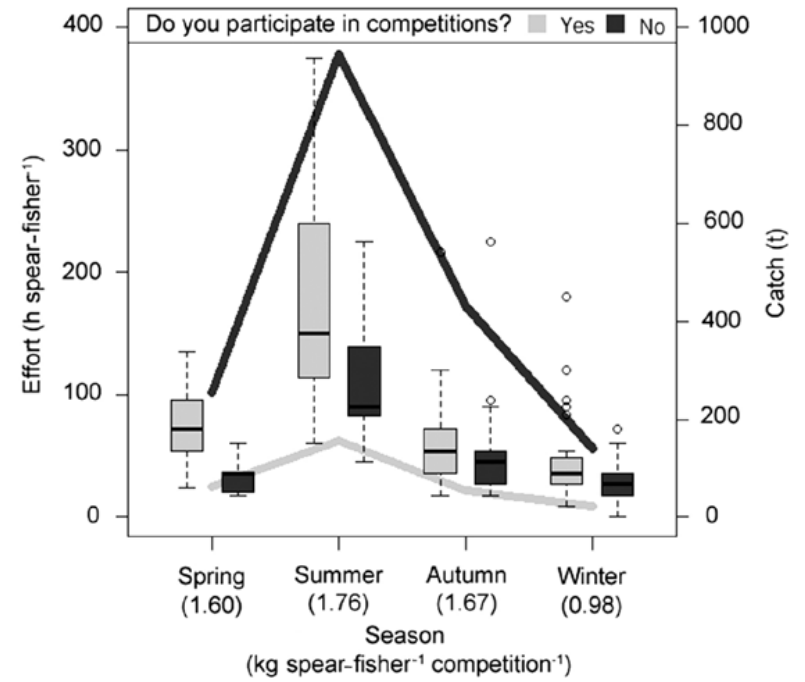

Fig. 5. - Seasonal fishing effort exerted by the Galician spear fishers, determined by electronic interviews $(\mathrm{N}=54)$. The top and bottom parts of the boxes correspond to the first and third quartiles of the data, the whiskers extend up to 1.5 times the interquartile range and the median is indicated with a horizontal line. The lines show the catches estimated for the spear fishers in 2007. The average seasonal CPUE, obtained from the FEGAS archive, used for the estimates are shown in brackets. The spear fishers that participated in competitions $(\mathrm{N}=500)$ and those that did not $(\mathrm{N}=4790)$ were treated separately. The estimates of non-competitive spear fishers are shown for comparative purposes and should be used with care (see text for details).

spear fishers. Therefore, combining the seasonal fishing effort obtained in the questionnaires with the seasonal average CPUE obtained from the FEGAS archive, their annual recreational catch was $295 \mathrm{t}$ (Fig. $5)$. On the other hand, if the annual catch taken during competitions was added, their overall catch would be $297 \mathrm{t}$ (Table 1).

The recreational catches of competitive spear fishers accounted for $2.7 \%$ of the combined annual catch of recreational and commercial fisheries operating in coastal waters on the 29 species common to both fisheries (Xunta de Galicia 2015, the official fisheries statistics are available at http://www.pescadegalicia. com). However, competitive spear fishers were very selective, concentrating $95.0 \%$ of their catches on six of their targeted species: L. bergylta, Dicentrarchus labrax (L.), D. annularis, D. sargus, D. vulgaris and $B$. capriscus. Thus, recreational catches on L. bergylta $(222 \mathrm{t})$, the most important species for this fishery (74.7\% of total), almost equalled commercial catches (266 t). Moreover, recreational catches on Diplodus cervinus (Lowe), Seriola dumerili (Risso), B. capriscus and Muraena helena (L.) were higher than commercials. In addition, spear fishers obtained a large proportion of catches of D. labrax and D. sargus, species with high commercial values $(6.6 \%$ and $3.0 \%$, respectively, Table 1).

\section{Vulnerability of fish species}

The mean intrinsic vulnerability to fishing of the fish species caught by the recreational spear fishery in Galicia is low (36.7), ranging from low (D. annularis vulnerability is 21 ) to very high (C. conger is 86 ). Furthermore, less than a third of the species targeted by spear fishers $(24.1 \%)$ are highly to very highly vulnerable to fishing pressure. Moreover, with the exception of D. labrax, with moderate vulnerability (42), the most caught species show low vulnerabilities (Table 1).

The mean vulnerability of the commercial catch on the species common to both fisheries is moderate (56.5). However, it should be noted that $C$. conger, the most caught species (33.9\% of the commercial catch) is the only species that shows very high vulnerability (Table 1).

\section{DISCUSSION}

Considerable fishing effort (107.2 \pm 71.8 spear-fishers $h$ ) is exerted in spearfishing competitions. Furthermore, the weighing of landings is an open and public procedure that, especially when catches are abundant, has come to cause conflicts with other stakeholders and negative impacts on public opinion (Pita pers. obs.). However, the abundances of coastal fish assemblages do not seem to be affected by previous competitions held in the area (Fig. 2). In fact, the historic catches obtained in competitions are relatively small, $101 \mathrm{t}$ in 54 years, which only accounts for $1 \%$ of the annual landings of the same species made by commercial fleets (Table 1).

On the other hand, the large reduction $(83 \%)$ in the abundances of L. bergylta shown after major spearfishing competitions seems to be due to the direct impact of these events (Fig. 4). This impact could be due to the fact that L. bergylta is a sedentary species (Darwall et al. 1992, Pita and Freire 2011, Villegas-Ríos et al. 2013 b) that would be particularly affected by competitions with many participants in a constrained area. Nevertheless, the model fitted to this species (Table 3) did not show a time effect, suggesting that the populations recover quickly, probably due to immigration from nearby areas or from deeper waters (Lindfield et al. 2014).

It must be noted that Galician spear fishers mainly target large carnivore fish, including the main coastal top-predators (Table 1), avoiding the smaller species of the ecosystem (Pita et al. 2014). Large predators have been widely used as indicators of ecosystem health due to their K-selected life-history strategies, which make them very vulnerable to fishing (e.g. Myers and Worm 2003, Myers et al. 2007). However, the species targeted by spear fishers in Galicia are on average not very vulnerable to fishing pressure ( $I V=37$, Table 1 ). Actually, their average vulnerability is lower than the vulnerability found in other spear fisheries, e.g. in the Mediterranean (IV=54, Lloret et al. 2008) and in the Atlantic Ocean (IV=50.9, Diogo and Pereira 2014). It also should be noted that among the preferred targets of Galician spear fishers, i.e. L. bergylta, D. labrax and $D$. sargus, abundant and frequent species of coastal ecosystems (Pita et al. 2014), only D. labrax is moderately vulnerable to fishing (Table 1).

However, the recreational catches of L. bergylta, D. labrax and D. sargus are, at least, large compared 
with commercial catches (Table 1). Furthermore, the removal of large individuals of sequential hermaphrodites like L. bergylta (Dipper et al. 1977) and Diplodus spp. (Bauchot and Hureau 1986), generally of the same sex, may reduce their long-term reproductive rates (Darwall et al. 1992, Birkeland and Dayton 2005). In addition, depth ranges of $L$. bergylta and D. sargus overlap with depths at which spear fishers operate (Table 1). Thus, spear fishing should have a greater impact on these species than on others that have shelter in deep waters (Lindfield et al. 2014). Moreover, taking into account the questionnaires answered by spear fishers who do not participate in competitions (Fig. 5), the Galician recreational spear fishery (competitive and non-competitive) accounted for $16 \%$ of the annual catches of the species common to commercial fisheries. In fact, this is a similar figure to that obtained by Lloret et al. (2008) in a Mediterranean spear fishery (29\%). In this case, recreational catches on L. bergylta (1447 t) would be even higher than commercial catches (266 t). Moreover, recreational catches of D. labrax (136 t) and D. sargus $(73 \mathrm{t})$ would be similar to commercials ( 277 $\mathrm{t}$ and $345 \mathrm{t}$, respectively).

As Lloret and Font (2013) found in the Mediterranean Sea, Galician spear fishers were reluctant to provide information on their fishery. Because of this, their fishing effort was estimated using a limited number of questionnaires in the case of the spear fishers who did not participate in competitions. The estimates of the recreational catches obtained by non-competitive spear fishers were also obtained using the CPUE derived from the FEGAS archive. These estimates are very robust because were based on a high number of observations, but they could be biased because the efficiency of the competitive spear fishers is probably higher than that of the non-competitive ones (Lincoln Smith et al. 1989). For all those reasons, the recreational catch estimated for non-competitive spear fishers should be taken with caution.

The fishing effort shown by the Galician spear fishers was similar to the effort shown by other spear fishers in nearby regions, such as the Azores Islands (N Atlantic). Most of the non-competitive spear fishers spent $3.0 \mathrm{~h}$ per fishing journey in Galicia, averaging 65 fishing operations per year. In the Azores, they spent $1.9 \mathrm{~h}$ per day (Diogo and Pereira 2014), performing on average 22 fishing operations per year (Diogo and Pereira 2013). The lower fishing effort exerted in the Azores Islands could be explained by the high wave exposure of these oceanic islands, which prevented the completion of more than half of the available fishing days (Diogo and Pereira 2013). Probably for this reason, the spear fishers in the Azores Islands showed a greater preference for the summer season than those in Galicia (Diogo and Pereira 2014). By contrast, the Galician coastline, with many bays and small islands, provides harbourage for the practice of this activity in a wider range of environmental conditions. Furthermore, the overall mean CPUE estimated in this study, 1.6 $\mathrm{kg}$ spear-fisher ${ }^{-1} \mathrm{~h}^{-1}$, was very similar to the average found in other works, $1.3 \mathrm{~kg}$ spear-fisher ${ }^{-1} \mathrm{~h}^{-1}$ (a comparative analysis is shown in Diogo and Pereira 2013).
Indeed, both the estimates on fishing effort and catches of non-competitive spear fishers shown in this study are important in the data-poor environment in which these fisheries are currently managed, because they provide valuable benchmarks that can be used until further research is conducted in the future.

It must also be considered that the recreational catch was distributed among the target species by using the information on the frequency of the trophy fish in the FEGAS archive. Since this is a record of the heavier fish, the recreational catch of the larger species could have been overestimated. However, to minimize distortions in favour of the heavier fish, the minimum catch percentage $(0.01 \%)$ for those species absent from the trophy fish record was conservatively added. Furthermore, the frequencies of the trophy fish record are in general congruent with the frequencies and the abundances shown in the UVCs of this and other studies in the area (Pita et al. 2014). Consequently, since the trophy fish record reflects the natural abundances of the coastal fish, it also provides a good tool for estimating the recreational catches of the spear fishers.

It is widely recognized that illegal, unreported and unregulated (IUU) fishing is a common practice in spear fishing (Ramdeen et al. 2013) and commercial fisheries (Watson and Pauly 2001, Pauly et al. 2002, Zeller and Pauly 2005, Pauly 2009). Because of their very nature, it is especially difficult to calculate the IUU catches of the commercial fleet in Galicia, but it has been estimated that they are usually several times larger than the official catches (FAO 2012). For that reason, real commercial catches are probably higher than those shown in Table 1. Consequently, although some of the comparisons made in this study between recreational and commercial fisheries may experience variations in either direction, the estimates of the overall catch and its distribution among the species are correct and constitute valuable information for management. Moreover, as suggested for the South Pacific (Godoy et al. 2010), the Coral Sea (Frisch et al. 2012), the Mediterranean Sea (Coll et al. 2004, Morales-Nin et al. 2005, Lloret et al. 2008, Lloret and Font 2013) and the Atlantic (Diogo and Pereira 2013, 2014), the evidence presented here showed that the impact of the recreational spear fishers must be taken into consideration in the management models of the coastal ecosystems of Galicia.

In coastal seas, humans have overexploited more than $90 \%$ of their economically relevant species (Lotze et al. 2006). In Galicia, as in the rest of the European seas (Froese and Proelß 2010), there is growing concern regarding the long-term sustainability of local fish stocks (Freire and García-Allut 2000, Freire et al. 2002, Pita and Freire 2014). In this regard, it must be noted that of the 29 species targeted by this recreational fishery only $C$. conger supports a large commercial fishing effort (Pita et al. 2008). Therefore, unlike what was found in the Mediterranean (Lloret and Font 2013) and in the Atlantic (Diogo and Pereira 2013), most of these species are not preferred objectives of the commercial fleet (Xunta de Galicia 2015, http://www.pescadegali- 
cia.com), which exploits over 100 different species (Freire and García-Allut 2000). By way of illustration, $149547 \mathrm{t}$ of coastal fish were commercialized in Galicia in 2007, 72 times more than the catch of the Galician spear fishery. Consequently, unlike what was established for the Mediterranean (Coll et al. 2004), it seems that the commercial fishery may also play a role in the current overexploitation of the Galician coastal ecosystems (Pita and Freire 2014).

Approximately $90 \%$ of the annual recreational licences issued in Galicia are for boat and shore fishing (Xunta de Galicia, pers. comm). This hook and line recreational fishery shares the same bag limit as that of spear fishers (currently $5.0 \mathrm{~kg}$ fisher ${ }^{-1}$ day $^{-1}$ ), but there is no limitation on the number of fishing days (Xunta de Galicia 2009). Therefore, their catches should be higher than those of spear fishers, but their impact has not yet been studied. Further research efforts are urgently needed to ensure the preservation of these coastal ecosystems, taking into account that the recently reformed European Common Fishery Policy encourages an integrated management of the coastal areas, including the use of these ecosystems by the commercial and the recreational fisheries, among other stakeholders (European Parliament and Council 2013).

The use of recreational fishing-dependent data to study impacts on fisheries has received little interest (Post et al. 2002, Coleman et al. 2004, Cooke and Cowx 2004, Lewin et al. 2006, Pawson et al. 2008, Zeller et al. 2008). Even less attention has been paid to the information derived from spear fishers (Smith and Nakaya 2002). In this work, the use for the first time of spearfishing competition catch and effort data crossed with UVC monitoring programmes has proven to be a very valuable tool for the management of the coastal ecosystems. This approach is especially recommended to reconstruct the effect of fishing on fish populations in data-limited situations and to inform management decisions. Moreover, many recreational organizations retain historic records, such as the FEGAS archive used here, that could be very informative about changes in marine ecosystems, especially for species of low commercial interest. Special care must be taken with vulnerable species targeted by both recreational and commercial fishers like $C$. conger and $D$. labrax. In addition, some kind of protection measures may also be needed to ensure the conservation of rare, less abundant, large and highly vulnerable species such as Argyrosomus regius (Asso), M. helena, D. cervinus, Dentex dentex (L.), L. mixtus, Galeorhinus galeus (L.) and Scyliorhinus canicula (L.).

\section{ACKNOWLEDGEMENTS}

This research was funded by the Autonomous Government of Galicia, Xunta de Galicia (Plan Galego de Investigación, Desesnvolvemento e Innovación Tecnolóxica), PECOS project (PGIDIT05RMA10301PR). The authors thank Mr. Enrique Brandariz and Mr. Manuel Segade, former chairman and secretary of the FEGAS, for their valuable support.

\section{REFERENCES}

Akaike H. 1973. Information theory and an extension of the maximum likelihood principle. In: Petrov B.N., Csaki F. (eds), Second International Symposium of Information Theory. Budapest.

Arlinghaus R. 2006. Overcoming human obstacles to conservation of recreational fishery resources, with emphasis on central Europe. Environ. Conserv. 33: 46-59. http://dx.doi.org/10.1017/S0376892906002700

Bauchot M.L. 1987. Poissons osseux. In: Fischer W., Bauchot M.L., Schneider M. (eds), Fiches FAO d'identification pour les besoins de la pêche. (rev. 1). Méditerranée et mer Noire. Zone de pêche 37. Commission des Communautés Européennes and FAO, Rome.

Bauchot M.L., Hureau J.C. 1986. Sparidae. In: Whitehead P.J.P., Bauchot M.L., Hureau J.C., et al. (eds), Fishes of the Northeastern Atlantic and the Mediterranean. UNESCO. Paris.

Birkeland C., Dayton P.K. 2005. The importance in fishery management of leaving the big ones. Trends. Ecol. Evol. 20: 356-358. http://dx.doi.org/10.1016/j.tree.2005.03.015

Cheung W.W.L., Pitcher T.J., Pauly D. 2005. A fuzzy logic expert system to estimate intrinsic extinction vulnerabilities of marine fishes to fishing. Biol. Conserv. 124: 97-111. http://dx.doi.org/10.1016/j.biocon.2005.01.017

Cheung W.W.L., Watson R., Morato T., et al. 2007. Intrinsic vulnerability in the global fish catch. Mar. Ecol. Prog. Ser. 333: 1-12. http://dx.doi.org/10.3354/meps333001

Coleman F.C., Figueira W.F., Ueland J.S., et al. 2004. The Impact of United States Recreational Fisheries on Marine Fish Populations. Science 305: 1958-1960. http://dx.doi.org/10.1126/science.1100397

Coll J., Linde M., García-Rubies A., et al. 2004. Spear fishing in the Balearic Islands (west central Mediterranean): species affected and catch evolution during the period 1975-2001. Fish. Res. 70: 97-111. http://dx.doi.org/10.1016/j.fishres.2004.05.004

Cooke S.J., Cowx I.G. 2004. The role of recreational fishing in global fish crises. BioScience 54: 857-859. http://dx.doi.org/10.1641/0006-3568(2004)054[0857:TRORFI ]2.0.CO;2

Cooke S.J., Cowx I.G. 2006. Contrasting recreational and commercial fishing: Searching for common issues to promote unified conservation of fisheries resources and aquatic environments. Biol. Conserv. 128: 93-108 http://dx.doi.org/10.1016/j.biocon.2005.09.019

Darwall W.R.T., Costello M.J., Donnelly R., et al. 1992. Implications of life-history strategies for a new wrasse fishery. J. Fish Biol. 41: 111-123. http://dx.doi.org/10.1111/j.1095-8649.1992.tb03873.x

De Girolamo M., Mazzoldi C. 2001. The application of visual census on Mediterranean rocky habitats. Mar. Environ. Res. 51: $1-16$. http://dx.doi.org/10.1016/S0141-1136(00)00028-3

Diogo H.M.C., Pereira J.G. 2013. Impact evaluation of spear fishing on fish communities in an urban area of São Miguel Island (Azores Archipelago). Fish. Manag. Ecol. 20: 473-483. http://dx.doi.org/10.1111/fme.12036

Diogo H., Pereira J.G. 2014. Assessing the potential biological implications of recreational inshore fisheries on sub-tidal fish communities of Azores (north-east Atlantic Ocean) using catch and effort data. J. Fish Biol. 84: 952-970. http://dx.doi.org/10.1111/jfb.12336

Dipper F.A., Bridges C.R., Menz A. 1977. Age, growth and feeding in the ballan wrasse Labrus bergylta Ascanius 1767. J. Fish Biol. 11: 105-120. http://dx.doi.org/10.1111/j.1095-8649.1977.tb04103.x

European Parliament and Council. 2013. The Common Fisheries Policy, amending Council Regulations (EC) No 1954/2003 and (EC) No 1224/2009 and repealing Council Regulations (EC) No 2371/2002 and (EC) No 639/2004 and Council Decision 2004/585/EC. 1380/2013. Official Journal of the European Union, Brussels.

FAO. 2012. The State of World Fisheries and Aquaculture. FAO, Rome.

Freire J., García-Allut A. 2000. Socioeconomic and biological causes of management failures in European artisanal fisheries: the case of Galicia (NW Spain). Mar. Policy 24: 375-384. http://dx.doi.org/10.1016/S0308-597X(00)00013-0

Freire J., Bernárdez C., Corgos A., et al. 2002. Management strategies for sustainable invertebrate fisheries in coastal ecosystems 
of Galicia (NW Spain). Aquat. Ecol. 36: 41-50. http://dx.doi.org/10.1023/A:1013350723445

Frisch A.J., Cole A.J., Hobbs J-P.A., et al. 2012. Effects of spearfishing on reef fish populations in a multi-use conservation area. PLoS One 7: e51938. http://dx.doi.org/10.1371/journal.pone.0051938

Froese R., Proelß A. 2010. Rebuilding fish stocks no later than 2015: will Europe meet the deadline? Fish Fish. 11: 194-202. http://dx.doi.org/10.1111/j.1467-2979.2009.00349.x

Godoy N., Gelcich S., Vasquez J., et al. 2010. Spearfishing to depletion: Evidence from temperate reef fishes in Chile. Ecol. Appl. 20: $1504-1511$.

http://dx.doi.org/10.1890/09-1806.

Gust N., Choat J.H., McCormick M.I. 2001. Spatial variability in reef fish distribution, abundance, size and biomass: a multi scale analysis. Mar. Ecol. Prog. Ser. 214: 237-251. http://dx.doi.org/10.3354/meps214237

Harmelin J.G., Bachet F., Garcia F. 1995. Mediterranean marine reserves: fish indices as tests of protection efficiency. Mar. Ecol. 16: $233-250$. http://dx.doi.org/10.1111/j.1439-0485.1995.tb00408.x

Hastie T., Tibshirani R.J. 1990. Generalized Additive Models. Chapman and Hall, London.

Jouvenel J.Y., Pollard D.A. 2001. Some effects of marine reserve protection on the population structure of two spearfishing target-fish species, Dicentrarchus labrax (Moronidae) and Sparus aurata (Sparidae), in shallow inshore waters, along a rocky coast in the northwestern Mediterranean Sea. Aquatic Conservation: Mar. Freshw. Ecosys. 11: 1-9. http://dx.doi.org/10.1002/aqc.424

Kearney R.E. 2001. Fisheries property rights and recreational/commercial conflict: implications of policy developments in Australia and New Zealand. Mar. Policy 25: 49-59. http://dx.doi.org/10.1016/S0308-597X(00)00035-X

Kirkegaard I.R., Gartside D.F. 1998. Performance indicators for management of marine recreational fisheries. Mar. Policy 22: 413-422. http://dx.doi.org/10.1016/S0308-597X(98)00003-7

Lewin W.C., Arlinghaus R., Mehner T. 2006. Documented and potential biological impacts of recreational fishing: insights for management and conservation. Rev. Fish. Sci. 14: 305-367. http://dx.doi.org/10.1080/10641260600886455

Lincoln Smith M.P., Bell J.D., Pollard D.A., et al. 1989. Catch and effort of competition spearfishermen in southeastern Australia. Fish. Res. 8: 45-61. http://dx.doi.org/10.1016/0165-7836(89)90040-4

Lindfield S.J., McIlwain J.L., Harvey E.S. 2014. Depth refuge and the impacts of SCUBA spearfishing on coral reef fishes. PloS One 9: e92628. http://dx.doi.org/10.1371/journal.pone.0092628

Lotze H.K.L., Lenihan H.S., Bourque B.J., et al. 2006. Depletion, degradation, and recovery potential of estuaries and coastal seas. Science 312: 1806-1809. http://dx.doi.org/10.1126/science.1128035

Lloret J., Font T. 2013. A comparative analysis between recreational and artisanal fisheries in a Mediterranean coastal area. Fish. Manage. Ecol. 20: 148-160. http://dx.doi.org/10.1111/j.1365-2400.2012.00868.x

Lloret J., Zaragoza N., Caballero D., et al. 2008. Spearfishing pressure on fish communities in rocky coastal habitats in a Mediterranean marine protected area. Fish. Res. 94: 84-91. http://dx.doi.org/10.1016/j.fishres.2008.07.002

Micheli F., Benedetti-Cecchi L., Gambaccini S., et al. 2005. Cascading human impacts, marine protected areas, and the structure of Mediterranean reef assemblages. Ecol. Monogr. 75: 81-102. http://dx.doi.org/10.1890/03-4058

Morales-Nin B., Moranta J., García C., et al. 2005. The recreational fishery off Majorca Island (western Mediterranean): some implications for coastal resource management. ICES J. Mar. Sci. 62: 727-739. http://dx.doi.org/10.1016/j.icesjms.2005.01.022

Myers R.A., Worm B. 2003. Rapid worldwide depletion of predatory fish communities. Nature 423: 280-283. http://dx.doi.org/10.1038/nature01610

Myers R.A., Baum J.K., Shepherd T.D., et al. 2007. Cascading effects of the loss of apex predatory sharks from a coastal ocean. Science 315: 1846-1850. http://dx.doi.org/10.1126/science.1138657

Pais A., Azzurro E., Guidetti P. 2007. Spatial variability of fish fauna in sheltered and exposed shallow rocky reefs from a re- cently established Mediterranean Marine Protected Area. Ital. J. Zool. 74: 277-287.

http://dx.doi.org/10.1080/11250000701456984

Pauly D. 2009. Beyond duplicity and ignorance in global fisheries. Sci. Mar. 73: 215-224.

http://dx.doi.org/10.3989/scimar.2009.73n2215

Pauly D., Christensen V., Guénette S., et al. 2002. Towards sustainability in world fisheries. Nature 418: 689-695. http://dx.doi.org/10.1038/nature01017

Pawson M.G., Glenn H., Padda G. 2008. The definition of marine recreational fishing in Europe. Mar. Policy 32: 339-350. http://dx.doi.org/10.1016/j.marpol.2007.07.001

Pita P., Freire J. 2011. Movements of three large coastal predatory fishes in the northeast Atlantic: a preliminary telemetry study. Sci. Mar. 75: 759-770. http://dx.doi.org/10.3989/scimar.2011.75n4759

Pita P., Freire J. 2014. The use of spearfishing competition data in fisheries management: evidence for a hidden near collapse of a coastal fish community of Galicia (NE Atlantic Ocean). Fish. Manage. Ecol. 21: 454-469. http://dx.doi.org/10.1111/fme.12095

Pita P., Freire J., García-Allut A. 2008. How to assign a catch value to fishing grounds when fisheries statistics are not spatially explicit. Sci. Mar. 72: 693-699. http://dx.doi.org/10.3989/scimar.2008.72n4693

Pita P., Fernández-Márquez D., Freire J. 2014. Short-term performance of three underwater sampling techniques for assessing differences in the absolute abundances and in the inventories of the coastal fish communities of the Northeast Atlantic Ocean. Mar. Freshw. Res. 65: 105-113. http://dx.doi.org/10.1071/MF12301

Post J.R., Sullivan M., Cox S., et al. 2002. Canada's Recreational Fisheries: The Invisible Collapse? Fisheries 17: 6-17. http://dx.doi.org/10.1577/1548-8446(2002)027<0006:CRF>2.0.CO;2

Ramdeen R., Harper S., Frotté L., et al. 2013. Reconstructed Total Catches by the Marine Fisheries of Small Island States in the Wider Caribbean (1950-2010). 65th Gulf and Caribbean Fisheries Institute, Santa Marta.

R Core Team. 2008. R: A language and environment for statistical computing. R Foundation for Statistical Computing. Vienna.

Rodríguez X., León X. 1997. Pesca Submarina en Galicia. Lea. Santiago de Compostela.

Rusell B.C. 1977. Population and standing crop estimates for rocky reef fishes of North-Eastern New Zealand. New Zealand J. Mar. Freshw. Res. 11: 23-36. http://dx.doi.org/10.1080/00288330.1977.9515659

Schmitt E.F., Sluka R.D., Sullivan-Sealey K.M. 2002. Evaluating the use of roving diver and transect surveys to assess the coral reef fish assemblage off southeastern Hispaniola. Coral Reefs 21: 216-223.

Schroeder D.M., Love M.S. 2002. Recreational Fishing and marine fish populations in California. California Cooperative Oceanic Fisheries Investigations, Santa Barbara.

Smith A., Nakaya S. 2002. Spearfishing. Is it ecologically sustainable? Third World Recreational Fishing Conference, Northern Territory, Australia.

Steffe A.S., Macbeth W.G., Murphy J.J. 2007. Status of the recreational fisheries in two Australian coastal estuaries following large fish-kill events. Fish. Res. 85: 258-269. http://dx.doi.org/10.1016/j.fishres.2007.02.003

Villegas-Ríos D., Alonso-Fernández A., Fabeiro M., et al. 2013a. Demographic Variation between Colour Patterns in a Temperate Protogynous Hermaphrodite, the Ballan Wrasse Labrus bergylta. PLoS One 8: e71591. http://dx.doi.org/10.1371/journal.pone.0071591

Villegas-Ríos D., Alós J., March D., et al. 2013b. Home range and diel behavior of the ballan wrasse, Labrus bergylta, determined by acoustic telemetry. J. Sea Res. 80: 61-71. http://dx.doi.org/10.1016/j.seares.2013.02.009

Watson R., Pauly D. 2001. Systematic distortions in world fisheries catch trends. Nature 414: 534-536. http://dx.doi.org/10.1038/35107050

Wood S.N. 2000. Modelling and smoothing parameter estimation with multiple quadratic penalties. J. Roy. Stat. Soc. B. 62: 413-428. http://dx.doi.org/10.1111/1467-9868.00240

Wood S.N. 2003. Thin plate regression splines. J. Roy. Stat. Soc. B. $65: 95-114$ http://dx.doi.org/10.1111/1467-9868.00374

Wood S.N. 2006. Generalized additive models: an introduction with 
R. Chapman \& Hall / CRC. Boca Raton.

Xunta de Galicia. 2009. Orde do 17 de setembro de 2009 pola que se desenvolve o Decreto 211/1999, do 17 de xuño, polo que se regula a pesca marítima de recreo, Santiago de Compostela.

Xunta de Galicia. 2015. Pesca de Galicia. Estadísticas oficiales de pesca de la Xunta de Galicia. Avilable at: http://www.pescadegalicia.com.

Yellen J.E., Brooks A.S., Cornelissen E., et al. 1995. A middle stone age worked bone industry from Katanda, Upper Semliki Valley, Zaire. Science 268: 553-556. http://dx.doi.org/10.1126/science.7725100

Zeller D., Pauly D. 2005. Good news, bad news: global fisheries discards are declining, but so are total catches. Fish Fish. 6: 156-159.

http://dx.doi.org/10.1111/j.1467-2979 2005.00177.x

Zeller D., Darcy M., Booth S., et al. 2008. What about recreational catch?: Potential impact on stock assessment for Hawaii's bottomfish fisheries. Fish. Res. 91: 88-97.

http://dx.doi.org/10.1016/j.fishres.2007.11.010 